\title{
Risk Analysis for Passenger of Online Motorcycle Public Transportation in The City of Jakarta
}

\author{
Achmad Sudiyar Dalimunthe ${ }^{1}$, Muhammad Ihsan ${ }^{1}$, Rukaesih Achmad Maolani ${ }^{2}$, \\ Dwi Haryanto ${ }^{3}$
}

\author{
${ }^{1}$ Management Study Program of Trisakti Insurance Management College \\ ${ }^{2}$ Centre of Research and Community Services of Trisakti Insurance Management College \\ ${ }^{3}$ Actuarial Study Program of Trisakti Insurance Management College \\ *Corresponding author. Email: dd.dalimunthe@gmail.com
}

\begin{abstract}
Traffic congestion encourages the need for fast, safe and inexpensive means of transportation for the community. The COVID-19 pandemic has also impacted many people in need of work to support themselves and their families. Being a driver of online motorcycle public transportation (ojol) is an alternative to earn income. This causes many online motorcycle public transportation (ojol) in big cities to be a rational choice for users of public transportation. This situation can have an impact on vehicle passengers, especially on security, safety and health risks. On this basis, researchers are interested in conducting research on the analysis of the risk of security, safety and health of passengers of online motorcycle public transportation. The type of research carried out is field research using quantitative methods and descriptive analysis approaches. This type of research requires researchers to be directly involved in the objects and activities carried out. Research respondents are passengers of online motorcycle public transportation in the city of Jakarta. Data collection techniques through interviews with questionnaires. There are three main outcomes that are targeted to be carried out in this research, namely, first, providing an analysis of security, safety and health risks for passengers of online motorcycle public transportation; second, providing recommendations on the need for risk mitigation for passengers of online motorcycle public transportation; third, introducing insurance as an effective and efficient risk mitigation tool related to risk management for passengers of online motorcycle public transportation.
\end{abstract}

Keyword: Risk Management, Online Motorcycle Public Transportation (Ojol), Traffic Accident, Risk Mitigation

\section{INTRODUCTION}

In principle, people need a means of transportation that is convenient, safe and cheap. Technological advances are also implemented in the field of transportation so that online transportation tools appear, which provide an online motorcycle taxi platform as a technology-based public transportation tool, which makes it easier for individuals to mobilize. Not everyone has their own vehicle as a means of transportation, so the emergence of two-wheeled vehicles or motorcycles as public transportation (ojek) has fulfilled the expectations of some people, especially people in big cities including Jakarta.

The increase in the number of motorized vehicles is certainly in line with the increase in traffic congestion in big cities, which affects the order and safety of road users in addition to air pollution which can cause disturbances to the health of drivers and passengers, especially users of two-wheeled motorized vehicles (ojek). 
The government has regulated transportation on the highway through Government Regulation number 37 of 2017 concerning Traffic Safety and Road Transportation, but sometimes there are noncompliance by road users. Violations committed by road users cause risks in the field of security and safety of road users, especially motorcycle users. In addition, air pollution due to traffic jams in big cities also poses a health risk to road users. Therefore, there is a need for a study to analyze the security, safety and health risks for passengers who often use motorcycle taxis as a means of daily transportation.

\section{THEORETICAL REVIEW}

\subsection{Motor Vehicle Public Transportation}

Act number 22 years of 2009 states that a motorized vehicle is any vehicle that is driven by mechanical equipment in the form of a machine other than a vehicle that runs on rails. Government Regulation number 14 years of 2014 concerning in more detail explains the grouping of motorized vehicles consisting of motorcycles, passenger cars, buses and goods cars. The main purpose of the existence of passenger public transportation according to [21] is to provide good and proper transportation services for the community safely, quickly, cheaply and comfortably.

The regulations governing motorized vehicles do not mention two-wheeled vehicles as public transportation, but their existence is currently widely used as a means of mobility of people and goods. This two-wheeled transportation, known as ojek, is in great demand by the public because in addition to being not too expensive, it can also speed up the journey even in a traffic jam situation that is often experienced in several cities in Indonesia.

The development of online application-based motorcycle taxi transportation is booming in Indonesia. This is because the ordering process is easy, the cost calculation is more transparent, and the service is also more satisfying compared to conventional motorcycle taxis or commonly called base motorcycle taxis. Currently, its development has reached major cities in Indonesia. The Indonesian Two-Wheel Action Association (GARDA) quoted by [11] revealed that the number of online motorcycle taxi drivers in Indonesia currently has more than 4 million people spread throughout Indonesia [16]. [12] states that currently there are several online motorcycle taxi applications operating in Indonesia, namely: Gojek, GrabMaxim, Anterin, Asia Trans, Get Indonesia, Oke Jack, Bonceng, TeknoJek, AdaJek, LadyJek, Ojesy.

\subsection{Risk Management}

Risk is defined as the uncertainty of financial loss or the possibility of loss. There are several classifications of risk, namely: Pure risk, which if it occurs will result in a loss, and if it does not occur it will not result in a loss or gain; and Speculative risk, which is related to the occurrence of two possibilities, to get a profit and get a loss. [15] states that an effort to reduce or minimize risk can be done by carrying out a risk control against uncertainties such as work accidents, natural disasters, robbery, theft and bankruptcy.

The risks faced need to be handled properly. One form of risk management is risk transfer, which is carried out through an insurance scheme. The insurance business is a mechanism that provides protection to the insured in the event of a risk in the future. If the risk actually occurs, the insured party will receive compensation for the amount agreed between the insurer and the insured.

Risk management is an effort to manage risk in a comprehensive, planned and systematic manner in order to prevent losses or accidents and assist in making better decisions by looking at the risks and impacts that can be caused. Indirectly, risk management also provides improvements in aspects of occupational safety, health, compliance with laws and regulations, environmental protection, public perception, product quality, corporate governance, operating efficiency, and others. [21] states that the risk management process is an activity carried out by various institutions, continuously and consistently in order to apply the risk management process itself.

Determination of risk criteria is done by combining the criteria of likelihood and severity. The combination of the two can scale the risk events from low, medium to high risk. The first stage in risk management is risk identification which is carried out to identify or to answer questions what risks can occur, how and why they can occur. Risk identification aims to find out all sources of hazards and risky activities in a particular work activity or work process. The second stage is a risk assessment which is carried out through a process of risk analysis and risk evaluation. Risk analysis is carried out to determine the magnitude of a risk by considering the level of consequences (severity) and the possibility that can occur to take control actions. Risk Control is the third stage which is the efforts made to anticipate the occurrence of risk. Risk control can be carried out in various ways: elimination, substitution, engineering control, administrative control, and the use of personal protective equipment. 


\subsection{Research Focus}

In this study the problem is formulated to answer the questions:

a. What are the risks experienced by online motorcycle taxi passengers in the city of Jakarta?

b. What is the level of risk experienced by online motorcycle taxi passengers in the city of Jakarta?

This study limits the problem only to the security, safety and health risks of online motorcycle taxi passengers in the city of Jakarta

\section{RESEARCH METHOD}

The study was conducted in the city of Jakarta, with the research time starting from March to November 2021. The independent variables used are security risks, safety risks and health risks for passengers while driving using online motorcycle taxis on the highway. The research population is residents who usually use online motorcycle taxi services in the city of Jakarta, with a sample of 200 people taken using accidental sampling technique.

This study uses a quantitative method with a descriptive analysis approach, with the aim of: analyzing the possibility of security, safety and health risks experienced by passengers of twowheeled motorized vehicles on the highway; and take measurements of these risks based on: Frequency, Severity and Size (high $(\mathrm{H})$, medium (M), low (L)).

Data collection is carried out through an instrument in the form of a questionnaire to collect data about security, safety and health risks for online motorcycle taxi passengers. The parameters used to measure security risk are risk due to environmental conditions/road conditions, risk due to natural disasters, risk due to human actions, and risk due to human error. To measure safety risk, the parameters used are the risk of accidents by humans, accidents due to vehicles, accidents due to road conditions, and accidents due to the environment. Meanwhile, the parameters to measure health risk are the length of travel time per day, natural conditions (rainy season), air pollution, and traffic jams.

\section{RESEARCH FINDING}

To identify the risks experienced by online motorcycle taxi passengers, first an inventory of questions that are grouped into security risks, safety risks and health risks is carried out. The questions were prepared based on input from experts. After conducting a preliminary survey, then a validity test is carried out to ensure whether the instrument is valid to be included in the questionnaire that will be submitted to the respondents. Furthermore, from the results of data processing using SPSS, the reliability value is obtained to show how much the instrument can explain the risk in question.

In descriptive analysis, 200 respondents in the city of Jakarta are quite balanced between men and women, with a percentage of $56.5 \%$ being female and $43.5 \%$ being male. More than $50 \%$ of respondents have used online motorcycle taxis for more than 1 year. Respondents' answers were grouped into three Likert scales (never, never and often). To determine the level of risk, categorization is carried out by assigning 3 categories (low, medium, high), assuming that the subject population is normally distributed. By using the three Likert scales and the three level categories, as well as the normal curve range, and the subject population is normally distributed, the calculations and measurement results use categorization guidelines that refer to [5] which results in a low risk level, medium and high for each of the security, safety and health risks for online motorcycle taxi passengers

\subsection{The security risks of online motorcycle taxi passengers in the city of Jakarta}

The 19 (nine-teen) questions answered by the respondents, they were grouped into four dimensions of security risk, namely those related to traffic conditions and road users, those related to the behavior of motorcycle taxi drivers, those related to vehicle equipment, and those related to the attitudes and perceptions of motorcycle taxi passengers.

Based on the answers to all the questions that have been prepared for the security risk, respondents in the city of Jakarta indicate that for security risk the risk level consists of $58 \%$ low risk, $16 \%$ moderate risk and $26 \%$ high risk.

For online motorcycle taxi passengers, the Jakarta City security risk is triggered by the driver's habits or behavior, which is related to the availability of helmets that must always be available for passengers when using online motorcycle taxi services, then followed by the driver's habit of turning on the turn signal when the vehicle is driving. Online motorcycle taxis will turn either to the left or right from their initial position, the discipline of the driver to stop when the red light is on at the traffic light, and the driver provides helmets for passengers and the driver drops the passengers in a safe place. Meanwhile, the ten security risks that are included in the low category are the potential for bullying for passengers when riding online motorcycle taxis at night, then also the experience of passengers experiencing accidents in the form of a 
motorcycle collision with another motorcycle or an accident in the form of a motorcycle crash with a car, followed by with a fairly low potential for passengers to experience disrespectful treatment from online motorcycle taxi drivers and a fairly low potential for online motorcycle taxi drivers to ride their motorbikes when transporting passengers by riding on the sidewalk, also related to the behavior of breaking through traffic lights when the red light is on, low driver behavior who smoke when there are passengers, as well as the low potential for passengers to be snatched when getting off an online motorcycle taxi, and also the low number of passengers feeling uncomfortable riding together with online motorcycle taxi drivers and lastly, the low incidence of passengers onboard. $\mathrm{k}$ to the wrong address by an online ojek driver.

\subsection{The safety risk of online motorcycle taxi passengers in the city of Jakarta}

The 14 (four-teen) questions answered by the respondents, they were grouped into three dimensions of safety risk, namely those related to the behavior of motorcycle taxi drivers, those related to vehicle equipment, and those related to road traffic conditions.

Based on the answers to all the questions that have been prepared for these safety risks, respondents in the city indicated that $29 \%$ low risk, $14 \%$ moderate risk and $57 \%$ high risk, namely rearview mirror equipment for two-wheeled public transport vehicles that were boarded by passengers, availability of standard helmets. Indonesian National Standard (SNI) provided by drivers for passengers, motorcycle taxi drivers do not necessarily carry passengers on roads that are in safe areas, drivers lack driving ethics when on the highway, driver obedience behavior obeys road markings, opportunities for drivers to choose good roads when driving their vehicles on the road. the highway, the consistency of the driver to maintain a normal speed when driving with his passengers (not speeding), and the driver does not provide shelter opportunities during heavy rain when riding an ojek. However, there are four safety risks for passengers or users of two-wheeled public transportation services which are included in the low category, namely passengers experiencing accidents due to reckless driving, followed by a low risk of passengers having accidents due to drivers violating traffic regulations when driving., and the low risk of passengers experiencing accidents when driving on damaged road areas and the low number of ojek drivers using shortcuts against the current.

\subsection{Health risks of online motorcycle taxi passengers in the city of Jakarta}

The 12 (twelve) questions answered by the respondents, they were grouped into four dimensions of health risk, namely those related to the behavior of motorcycle taxi drivers, those related to road traffic conditions, those related to vehicle equipment, and those related to the attitudes and perceptions of motorcycle taxi passengers.

Based on the answers to all the questions that have been prepared for these health risks, respondents in the city of Jakarta indicated that $25 \%$ low risk, $50 \%$ moderate risk and $25 \%$ high risk.

As for the health risks of passengers or users of two-wheeled public transportation services, there are three risks that are included in the high category, namely the ojek drivers who ride always wear masks, then followed by the driver advising passengers to take shelter first when it rains and the ojek drivers who ride always provide raincoats. when it rains. Meanwhile, there are also three health risks of passengers or the use of two-wheeled public transportation services which are included in the low category, namely motorcycle taxi drivers smoking while driving a vehicle carrying passengers, then what is also low is the condition of the driver being sick when the passenger or service user will ride an ojek and passengers experience shortness of breath when in a very densely-traffic location.

\subsection{Risk Mitigation}

Based on the high level of risk that exists in security, safety and health risks, then risk mitigation is made. In the risk mitigation recommendations, the potential risks that may be experienced by passengers of two-wheeled public vehicles are influenced by several factors that have a major contribution, such as the driver's habits or behavior in driving so far, understanding to provide the best service to passengers, driver orientation prioritizing orders. next and not on the best service, standard specifications of two-wheeled public transportation manufacturers that must be maintained, standard equipment of two-wheeled public vehicles that must exist as operational requirements, awareness of the need to maintain and maintain the personal health of drivers and passengers.

For this reason, mitigation needs to be carried out by the motorcycle taxi driver by making selfpreparation, driving equipment, specifications and proper functioning of the vehicle used, programmatic and sustainable socialization of safety drivers, as well as a traffic environment supported by related agencies such as the Transportation 
Service, Traffic Service. and Road Transport and Traffic Police Units.

The discipline of motorcycle taxi drivers and the support of regulations that regulate and supervise motorcycle taxi driving activities are the driving force so that there is a reduction in the potential risks that will be experienced by motorcycle taxi passengers. There needs to be provisions for standardization of habits or behavior that drivers have when they want to become online motorcycle taxi drivers, there is also a need for standardization of driving equipment including standard specifications and vehicle functions that must be carried out, regular monitoring and audits carried out by online motorcycle taxi companies where the driver belongs. It would be better if the standardization was then set by the online motorcycle taxi management company and became a regulation on online motorcycle taxis, so that it became a recommendation to regulators and related agencies to make and determine the provisions of these regulation.

\section{CONCLUSION}

Based on data analysis and profiling of security, safety and health risks experienced by passengers using two-wheeled public transportation services operating on the DKI Jakarta metropolitan highway, it can be concluded as follows:

a) For security risk, the risk level consists of $58 \%$ low risk, $16 \%$ moderate risk and $26 \%$ high risk.

b) For safety risk, the risk level consists of $29 \%$ low risk, $14 \%$ moderate risk and $57 \%$ high risk.

c) For health risks, the risk consists of $25 \%$ low risk, $50 \%$ moderate risk and $25 \%$ high risk.

As explained the risks above, especially with medium and high levels, it is necessary to have mitigation carried out by both the driver himself and the risk mitigation carried out by the internal company where the online motorcycle taxi drivers are sheltered as well as regulations that are going concern about the three risks for vehicle passengers. the online motorcycle taxis, both from the Ministry of Health, the Ministry of the Environment, the Ministry of Transportation and the Police.

\section{REFERENCES}

[1] Undang-Undang Republik Indonesia Nomor 22 Tahun 2009. Lalu Lintas dan Angkutan Jalan:

https://pih.kemlu.go.id/files/uu_no_22 tahun 2009.pdf
[2] Peraturan Pemerintah Nomor nomor 14 tahun 2014 tentang Angkutan Jalan

[3] Abas, S., Asuransi \& Manajemen Risiko, Raja Grafindo Persada, Jakarta. 2007.

[4] Ayu Azizah dan Popon Rabia Adawia, Analisis Perkembangan Industri Transportasi Online di Era Inovasi Disruptif (Studi Kasus PTGojek Indonesia), 2018. Retrieved from https://ejournal.bsi.ac.id/ejurnal/index.php/cak rawala/article/view/4117

[5] Azwar, Saifuddin, Metode Penelitian Psikologi, Pustaka Pelajar, 2017

[6] Darmawi, H., Manajemen Risiko. Jakarta: Bumi Aksara. 2010.

[7] Djaja, S., Widyastuti, R., Tobing, K., Lasut, D., \& Irianto, J., Gambaran Kecelakaan Lalu Lintas di Indonesia, Tahun 2010-2014. Jurnal Ekologi Kesehtan, 2016, pp 30-42.

[8] International Labour Organization. Priority Safety and Health Issues in The Road Transport Sector. Retrieved from https://www.ilo.org/wcmsp5/groups/public/--ed_dialogue/--sector/documents/publication/wcms_400598.p df

[9] International Organization for Standardization. Startup Guide to ISO 39001 Road Traffic Safety Management Systems. 2017. Retrieved from

https://www.iso.org/files/live/sites/isoorg/files /developing_standards/docs/en/ISO_39001_St artup_Guide_2017-06.pdf

[10] Klugman, S. A., Panjer, H. H., \& Willmot, G. E., Loss Models From Data to Decisions Fourth Edition. Society of Actuaries. 2012.

[11] Kumparan.com. Organisasi Ojol: Ada 4 Juta Driver Ojol di Indonesia. 2020. https://kumparan.com/kumparantech/organisa si-ojol-ada-4-juta-driver-ojol-di-indonesia$\underline{\text { tBrZLEXOEI/full }}$

[12] Listiorini Ajeng Purvasthi. Aplikasi Ojek Online Terbaik dan Terpopuler di Indonesia, 2020. https://carisinyal.com/aplikasi-ojekonline/

[13] Ludyaningrum, R. M., Perilaku Berkendara dan Jarak Tempuh dengan Kejadian ISPA pada Mahasiswa Universitas Airlangga Surabaya. Jurnal Berkala Epidemiologi, 2017, pp 371383.

[14] J. McNeil, Alexander,. Frey Rudiger. Estimation of Tail-Related Risk Measures for 
Heteroscedastic Financial Time Series: an Extreme Value Approach. 1999.

[15] Muslich, Moh. Manajemen Risiko Operasional. Jakarta: PT Bumi Aksara. 2007.

[16] Menteri Perhubungan Republik Indonesia. Peraturan Menteri Perhubungan Republik Indonesia Nomor PM 12 Tahun 2019 tentang Perlindungan Keselamatan Pengguna Sepeda Motor yang Digunakan untuk Kepentingan Masyarakat. 2019. :http://jdih.dephub.go.id/assets/uudocs/perme n/2019/PM_12_TAHUN_2019.pdf

[17] Oldy Dumanauw, Paul A. T. Kawatu dan Nancy S. H. Malonda. Studi Perilaku Pada Pengendara Ojek Online Tentang Safety Riding Di Kota Manado. Jurnal KESMAS, Vol. 7 No. 5, 2018,

[18] Rukaesih A.Maolani dan A.S. Dalimunthe. Asuransi Mikro Untuk Pengemudi Angkutan Umum Sepeda Motor di DKI Jakarta. STMA Trisakti. Jakarta. 2019.

[19] Rudy Syafariansyah dan Erni Setiawati Dampak Tranportasi Online Terhadap Sosial Ekonomi Masyarakat. 2018. https://journal.uwgm.ac.id/index/php/ekonomi ka/index.

[20] Siahaan, Hinsa. Manajemen Risiko. Konsep, Kasus dan Implementasi. Jakarta: PT Elex Media Komputindo Kelompok Gramedia. 2007.

[21] Warpani, Suwardjoko. Merencanakan Sistem Perangkutan. Penerbit ITB. Bandung. 1990. 